\title{
Some New Heterocycles from the Reaction of 4-Carboxaldehyde-2-Phenyl-2H-1,2,3-Triazole Malononitrile
}

\author{
Mohamed A. El Sekily', Sohayla H. Mancy², A. M. El-Ghanam¹, G. A. Leon ${ }^{1}$ \\ ${ }^{1}$ Department of Chemistry, Faculty of Science, University of Alexandria, Alexandria, Egypt; ${ }^{2}$ Department of Physics \\ and Chemistry, Faculty of Education, University of Alexandria, Alexandria, Egypt
}

Correspondence to: Mohamed A. El Sekily, prof_dr_m_a_elsekily@yahoo.com

Keywords: Triazoles, Triazole Malononitrile, Pyrazole, Isoxazole

Received: October 26, 2017 Accepted: December 12, $2017 \quad$ Published: December 15, 2017

Copyright () 2017 by authors and Scientific Research Publishing Inc.

This work is licensed under the Creative Commons Attribution International License (CC BY 4.0).

http://creativecommons.org/licenses/by/4.0/

\section{(c) (i) Open Access}

\section{ABSTRACT}

Reaction of 4-carboxaldehyde-2-phenyl-2H-1,2,3-triazole 1 with malononitrile in presence of piperidine afforded the triazolomalonitrile 2 which on treatment with hydrazine hydrate, gave 3-amino-5-(2-phenyl-2H-1,2,3-triazol-4-yl)-4,5-dihydro-1-H-pyrazole-4-carbonitrile 3 and with hydroxylamine, gave 5-amino-3-(2-phenyl-2H-1,2,3-triazol-4-yl)-2,3-dihydroisoxazole-4-carbonitrile 4, and with thiourea, gave 2,4-diamino-6-(2-phenyl-2H-1,2,3-triazol4-yl)-6H-1,3-thiazine-5-carbonitrile 5. Similarly, reaction of 2 with ethanol amine, gave 2-amino-4-(2-phenyl-2H-1,2,3-triazol-4-yl)nicotinonitrile 6, and with thiosemicarbazide, gave 4-amino-2-hydrazinyl-6-(2-phnyl-2H-1,2,3-triazol-4-yl)-6H-1,3-thiazine-carbonitrile 7. Similary reaction of 2 with cyclopentanone gave, 2-amino-4-(2-phenyl-2H-1,2,3-triazol4-yl)-4,5,6,7-tetrahydrocyclopenta [6] pyran-3-carbonitrile 8. In addition, reaction of 1 with hydrazine hydrate, gave the 4 hydrazone which on treatment with another mole of 1 gave 10 and with 3-carboxaldehyde-1-phenyl-4,5-pyrazolinedione 4 phenylhydrazone gave compound 11 .

\section{INTRODUCTION}

Our continuous studies have demonstrated the utilization of carbohydrates specially L-ascorbic acid and its analogs in the synthesis of heterocycles including pyrazoles, triazoles, imidazoles and isoxazolines [1-5]. The observation that triazole and pyrazole derivatives are biologically active compounds [6-10] specially as insecticides and antiflamatory has promoted the extension of our study to synthesize a new series of this class of compounds in the hope of producing more effective chemotherapeutic agents. 


\section{RESULTS AND DISCUSSION}

Condensation of 4-carboxaldehyde-2-phenyl-2H-1,2,3-triazole 1 (obtained from the oxidation of D-glucosozone with cupper sulphate followed by periodate oxidation) with molononitrile in the presence of triethylamine, afforded the triazolomethylene malononitrite 2 whose ${ }^{1} \mathrm{H}$ NMR spectrum showed two singlets at $\delta 7.99$ and 8.53 for the ethylenic proton and the $\mathrm{C} 5-\mathrm{H}$ triazole ring respectively. Treatment of 2 with hydrazine hydrate in presence of piperidine, afforded the bicyclic compound, namely, 3-amino-5-(2-phenyl-2H-1,2,3-triazol-4-yl)-4,5-dihydro-1H-pyrazole-4-carbonitrile 3 (Scheme 1) whose structure was confirmed from its spectra and elemental analysis. Its ${ }^{1} \mathrm{H}$ NMR spectrum showed a singlet of two proton intensity at $\delta 5.35$ due to $\mathrm{NH}_{2}$ group, a doublet at $\delta 7.68\left(\mathrm{C}^{\prime}-\mathrm{H}\right)$ a doublet at $8.33\left(\mathrm{C} 4^{\prime}-\mathrm{H}\right)$ and a ginglet at $8.41(\mathrm{C} 5-\mathrm{H})$. The reaction of 2 with hydroxylamine hydrochloride, afforded the bicyclic compound 4 namely, 5-amino-3-(2-phenyl-2H-1,2,3-triazol-4-yl)-2,3-dihydroisoxazole-4-carbonitrile whose structure was confirmed by ${ }^{1} \mathrm{H}$ NMR which revealed a singlet at $\delta 5.53$ due to $\mathrm{NH}_{2}$ group , a singlet of one proton intensity at $\delta 7.56(\mathrm{C} 5-\mathrm{H})$ and a singlet at $\delta 8.39(\mathrm{C} 5-\mathrm{H})$. Furthermore treatment of 2 with thiourea in the presence of piperidine, gave 2,4-diamino-6-(2-phenyl-2H-1,2,3-triazol-4-yl)-6H-1,3-thiazine-5carbonitrile 5 whose structure was also confirmed by elemental analysis and NMR data. The ${ }^{1} \mathrm{H}$ NMR showed two singlets of one proton intensity each at $\delta 8.20(\mathrm{C} 6-\mathrm{H})$ and $8.48(\mathrm{C} 5-\mathrm{H})$. The reaction of 2 with ethanol amine, afforded 2-amino-4-(2-phenyl-2H-1,2,3-triazol-4-yl)nicotinonitrile 6 whose ${ }^{1} \mathrm{H}$ NMR revealed two doublets of one proton intensity each at $\delta 7.25\left(\mathrm{C} 5{ }^{\circ}-\mathrm{H}\right)$ and $7.89(\mathrm{C} 5-\mathrm{H})$. Moreover, treatment of 2 with thiosemicarbazide in presence of piperidine, gave 4-amino-2-hydrazinyl-6-(2-phenyl-2H-1,2,3triazol-4-yl)-6H-1,3-thiazine carbonitrile 7 whose structure was confirmed by ${ }^{1} \mathrm{H}$ NMR which showed three singlets of one proton intensity each at $\delta 8.20(\mathrm{C} 6-\mathrm{H}), 8.60(\mathrm{C} 5-\mathrm{H})$ and $11.69(\mathrm{NH})$. Finally treatment

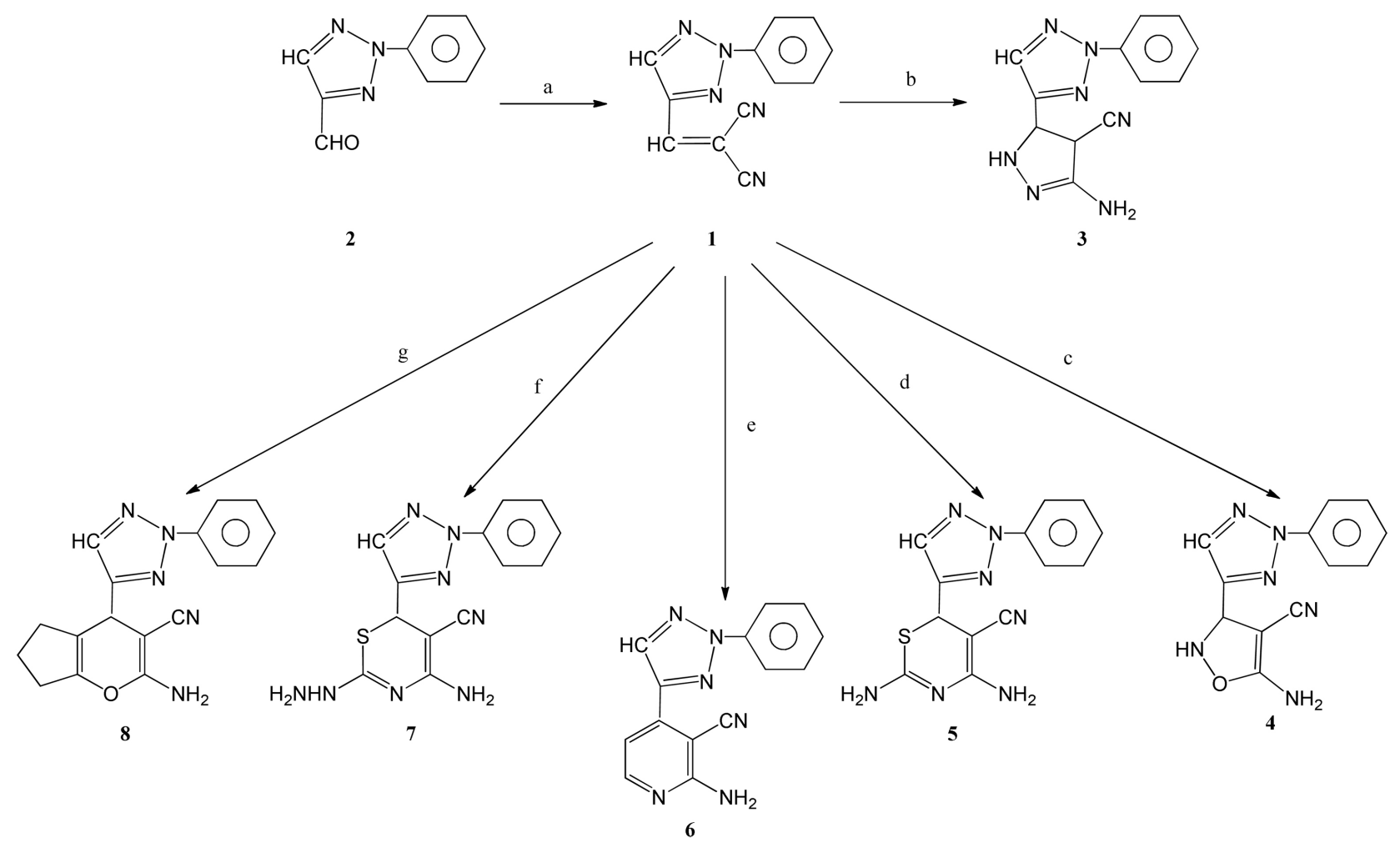

Scheme 1. Reagents and conditions: (a) $\mathrm{CH}_{2}(\mathrm{CN})_{2}, \mathrm{EtOH}$, triethylamine, $\Delta, 2 \mathrm{~h}$; (b) $\mathrm{NH}_{2} \mathrm{NH}_{2} \cdot \mathrm{H}_{2} \mathrm{O}$, EtOH, piperidine, $\Delta, 2 \mathrm{~h}$; (c) $\mathrm{NH}_{2} \mathrm{OH} \cdot \mathrm{HCl}, \mathrm{EtOH}$, piperidine, $\Delta, 2 \mathrm{H}$; (d) $\mathrm{NH}_{2} \mathrm{CSNH}_{2}, \mathrm{EtOH}$, piperidine, $\Delta, 2 \mathrm{~h}$; (e) $\mathrm{NH}_{2} \mathrm{CH}_{2} \mathrm{CH}_{2} \mathrm{OH}$, EtOH, piperidine, $\Delta, 2 \mathrm{~h}$; (f) $\mathrm{NH}_{2} \mathrm{NHCSNH}_{2}$, piperidine, $\Delta, 2$ $\mathrm{h} ; \mathrm{g}$ ) cyclopentanone, EtOH, piperidine, $\Delta, 2 \mathrm{~h}$. 
of 2 with cyclopentanone-gave 2-amino-4-(2-phenyl-2H-1,2,3-triazol-4-yl)-4,5,6,7-tetrahydrocyclo-penta [b] pyran-3-carbonitrile 8. Its structure was established from its elemental analysis and ${ }^{1} \mathrm{H} \mathrm{NMR}$ data which revealed two singlets of one proton intensity each at $\delta 8.42(\mathrm{C} 5-\mathrm{H})$ and $8.57\left(\mathrm{C}^{\prime}-\mathrm{H}\right)$ in addition to the expected proton signals. The reaction course leading to compounds 3-7 Scheme 2 from the triazole methylenemalononitrile can be assumed to proceed via the addition of the mercapto or amino groups at the ethylenic double bonds and thne nucleophilic attack of the amino or imino groups to the cyclized product except for the reaction of ethanol-amine, the reaction may proceed through the elimination of water molecule and nucleophilic attack of the amino group followed by elimination of $\mathrm{H}_{2}$ by auto oxidation. In addition, the reaction course leading to the formation of $\mathbf{8}$ from the triazole methylenemlonnitrile Scheme 2 can be assumed to proceed through the formation of cabanion fallowed by nucleophilic addition at the ethylenic bond and cyclization to give 8 . The reaction of 4-carboxaldehyde-2-phenyl-2H-1,2,3-triazole 1 with hydrazine hydrate, afforded 4-carboxaldehyde-4-hydrazone 9 which upon treatment with equivalent amount of 1 afforded 1,2-bis[(2-phenyl-2H-1,2,3-triazol-4-yl) methylen] hydrazine 10. Similarly treatment of 9 with 3-carboxaldehyde-1-phenyl-4,5-pyrazolinedione-4-phenylhydrazone, gave 1-phenyl3-[2-phenyl-2H-1,2,3-triazol-4-yl)-methylenehydrazonomethyl]-4-(phenylhydrazono)-1H-pyrazol-5(4H)one 11 (Scheme 3).

\section{EXPERIMENTAL}

\subsection{Apparatus and Materials}

Melting points were determined on a Kofler block and tottoli (Büchi) apparatus and are uncorrected.

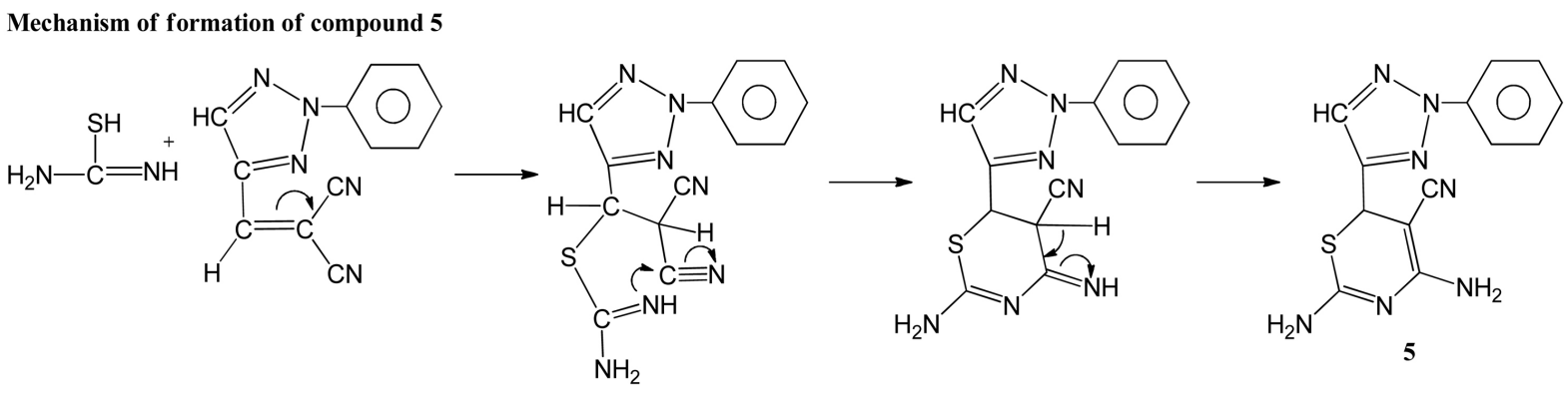

Mechanism of formation of compound 6
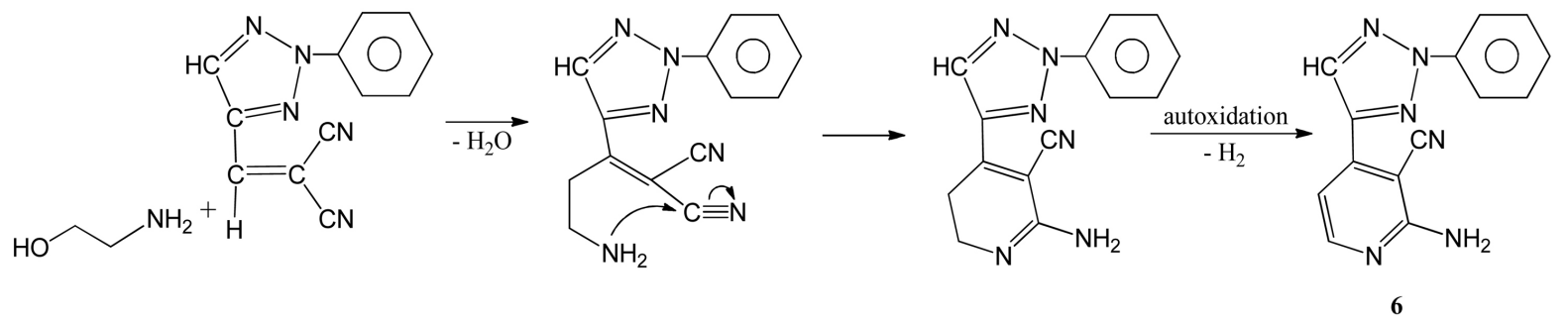

Mechanism of formation of compound 8

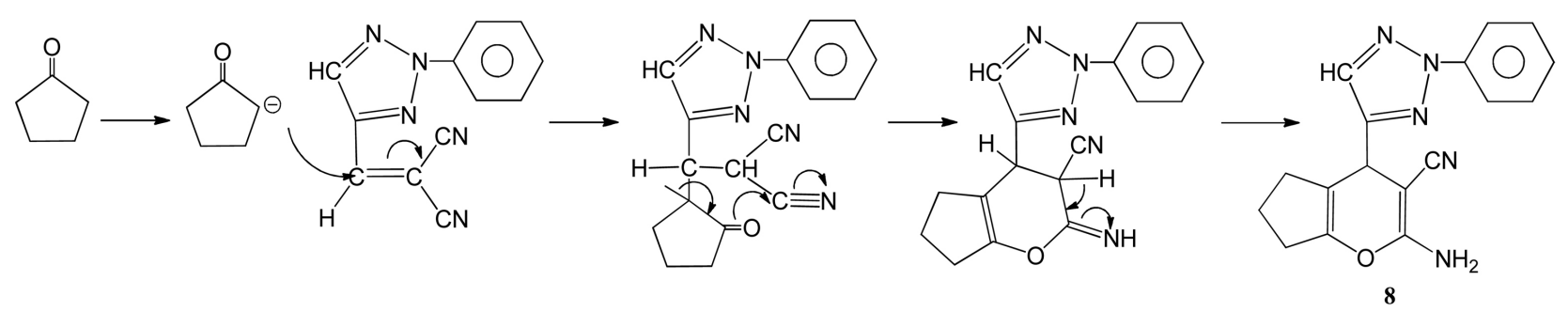

Scheme 2. Mechanisms of formation of compound 5, 6 and 8. 

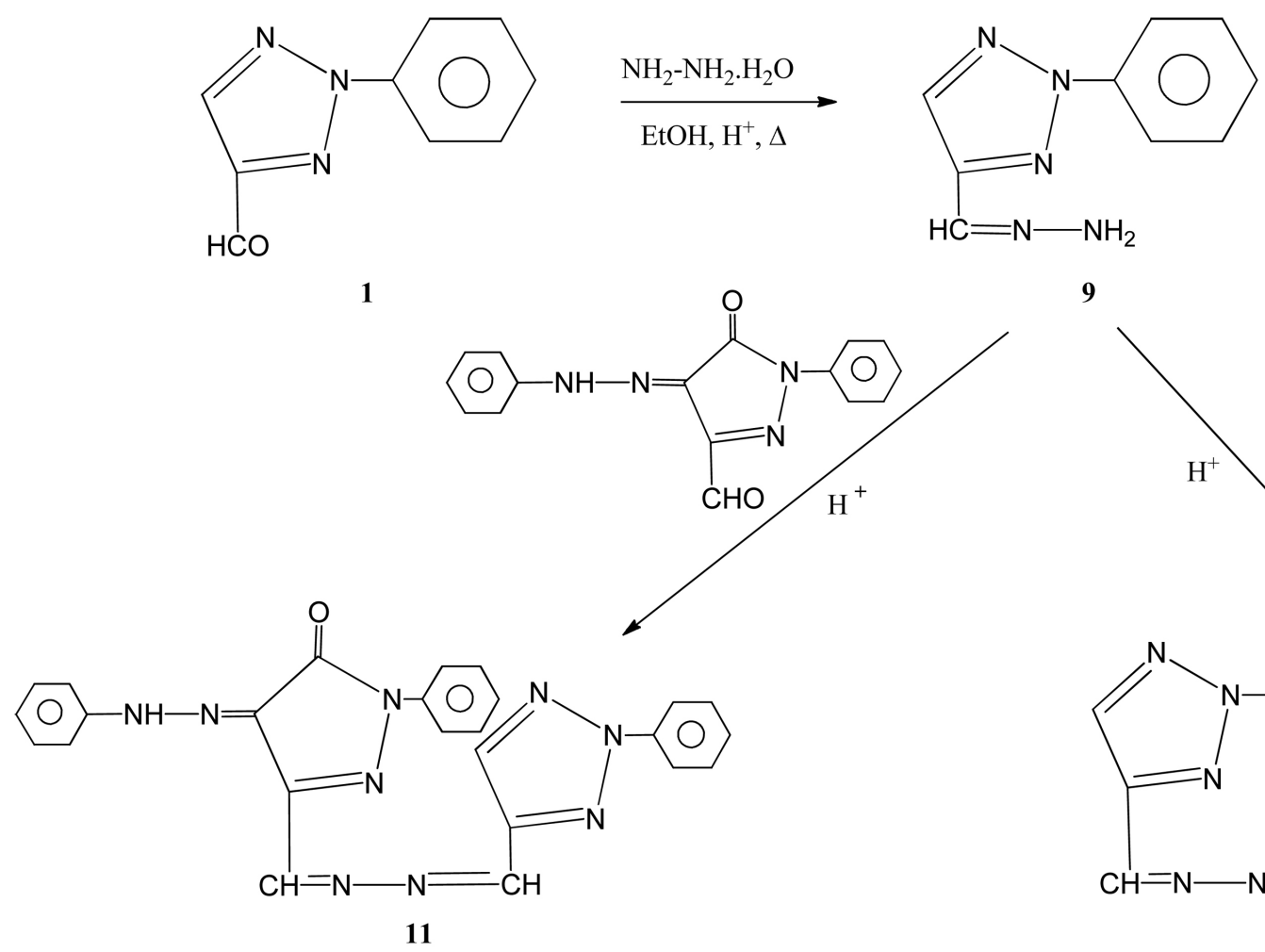

9
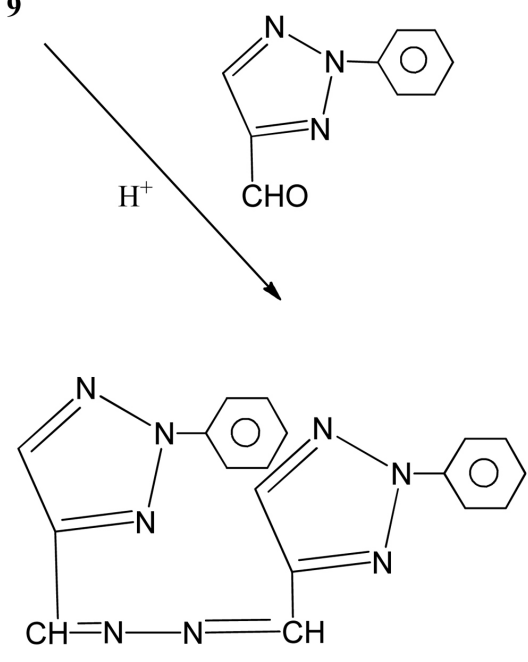

10

Scheme 3. Formation of compounds 9,10 and 11.

Elemental analyses were carried out in the microanalytical laboratory of the Faculty of Science, Cairo University. The IR spectra of compounds were recorded on a Perkin-Elmer 580B spectrophotometer as potassium bromide pellets and frequencies are reported in $\mathrm{cm}^{-1}$. The ${ }^{1} \mathrm{H}$ NMR spectra were recorded on a Cameca $250 \mathrm{NHz}$ spectrometer using TMS as internal standard. Mass spectra were recorded with LKB model 2091 spectrometer and intensities are given in parentheses as percentage of the base peak.

2-(2-Phenyl-2H-1,2,3-triazol-4-yI) methylenemalonomitrile (2) A solution of 1 (2 g, $11.5 \mathrm{mmol})$ in absolute ethanol $(30 \mathrm{ml})$ was treated with malononitrile $(0.94 \mathrm{~g}, 12 \mathrm{mmol})$ and few drops of triethylamine. The reaction mixture was heated under reflux for $2 \mathrm{~h}$, concentrated and left to fool. The yellow solid was filtered off, washed with ethanol and dried $(1.85 \mathrm{~g} ; 71 \%)$. It was recrystallized from ethanol as yellow needles m.p. $133^{\circ} \mathrm{C}-134^{\circ} \mathrm{C} ; v_{\max } / \mathrm{cm}^{-1} 2233(\mathrm{C} \equiv \mathrm{N})$ and $1609(\mathrm{C}=\mathrm{N})$; NMR: $\delta_{\mathrm{H}}\left(\mathrm{CDCl}_{3}\right) 7.99(\mathrm{~s}, 1 \mathrm{H}$, ethylinic proton), $7.40-8.14\left(\mathrm{~m}, 5 \mathrm{H}\right.$, aromatic-H), $8.53(\mathrm{~s}, 1 \mathrm{H}, \mathrm{C} 5-\mathrm{H}) ;{ }^{13} \mathrm{C} \mathrm{NMR}\left(\mathrm{CDCl}_{3}\right): \delta 147,138,137,119$, 112 , 84. Anal. Calc. for $\mathrm{C}_{12} \mathrm{H}_{7} \mathrm{~N}_{5}$ : C, 65.16; H, 3.17; N, 31.67. Found: $\mathrm{C}, 65.32 ; \mathrm{H}, 4.04 ; \mathrm{N}, 31.87 \%$.

\subsection{General Procedure}

A mixture of 2-(2-phenyl-2H-1,2,3-triazol-4-yl) methylenemalononitrile 2 ( $0.3 \mathrm{~g} ; 1.35 \mathrm{mmole})$ in absolute ethanol $(20 \mathrm{ml})$ was treated with an equimolar amount of hydrazine hydrate, hydroxylamine hydrochloride, thiourea, ethanol amine, thiosemicarbazide or cyclopentanone and few drops of piperidine. The clear solution was heated under reflux for $2 \mathrm{~h}$, concentrated, poured onto ice water and neutralized with acetic acid. The solid obtained was filtered off, washed with cold water, ethanol and dried. Each product was recrystallized from ethanol in needles.

3-Amino-5-(2-phenyl-2H-1,2,3-triazol-4-yl)-4,5-dihydro-1H-pyrazole-4-carbonitrile (3): (0.26 g; 81\%); m.p. $180^{\circ} \mathrm{C}-181^{\circ} \mathrm{C}$; IR: $v_{\max } / \mathrm{cm}^{-1} 3213\left(\mathrm{NH}_{2}\right), 2236(\mathrm{C} \equiv \mathrm{N})$ and $1612(\mathrm{C}=\mathrm{N}) ; \mathrm{NMR}: \delta_{\mathrm{H}}\left(\mathrm{CDCl}_{3}\right) 5.35(\mathrm{~s}$, $\left.2 \mathrm{H}, \mathrm{NH}_{2}\right), 6.19(\mathrm{~s}, 1 \mathrm{H}$, pyrazole $\mathrm{H}), 7.39-8.17(\mathrm{~m}, 5 \mathrm{H}$, aromatic- $\mathrm{H}), 7.68\left(\mathrm{~d}, 1 \mathrm{H}, \mathrm{j}_{5,4}=9.4 \mathrm{~Hz}, \mathrm{C} 5 \mathrm{\prime}-\mathrm{H}\right), 8.33$ (d. $\left.1 \mathrm{H} . \mathrm{J}_{5,4}=7.42 \mathrm{~Hz}, \mathrm{C} 4-\mathrm{H}\right), 8.41(\mathrm{~s}, 1 \mathrm{H}, \mathrm{C} 5-\mathrm{H}) .{ }^{13} \mathrm{C}$ NMR $\left(\mathrm{CDCl}_{3}\right): 153,136-134$ (aromatic C), 133, 129, 
128, 119. Anal. Calc. for $\mathrm{C}_{12} \mathrm{H}_{11} \mathrm{~N}_{7}: \mathrm{C}, 56.92 ; \mathrm{H}, 4.35 ; \mathrm{N}, 38.73$. Found: $\mathrm{C}, 56.78 ; \mathrm{H}, 4.42 ; \mathrm{N}, 38.52 \%$.

5-Amino-3-(2-phenyl-2 H-1,2,3-triazol-4-yl)-2,3-dihydroisoxazole-4-carbonitrile (4) (0.3 g; 76\%): m.p. $185^{\circ} \mathrm{C}-186^{\circ} \mathrm{C}$; IR: $v_{\max } / \mathrm{cm}^{-1} 3417(\mathrm{NH}), 2221(\mathrm{C} \equiv \mathrm{N})$ and $1625(\mathrm{C}=\mathrm{N})$; NMR: $\delta_{\mathrm{H}}\left(\mathrm{CDCl}_{3}\right) 5.35(\mathrm{~s}, 2 \mathrm{H}$, $\left.\mathrm{NH}_{2}\right), 7.42$ - $8.51\left(\mathrm{~m}, 5 \mathrm{H}\right.$, aromatic-H), $7.65\left(\mathrm{~s}, 2 \mathrm{H}, \mathrm{NH}_{2}\right), 7.65$ (s, 1H, C5'-H), 8.39 (s, 1H, C5-H), 9.26 (s, $1 \mathrm{H}$, isoxazole- $\mathrm{NH}$ ). Anal. Calc. for $\mathrm{C}_{12} \mathrm{H}_{10} \mathrm{~N}_{6} \mathrm{O}: \mathrm{C}, 56.69 ; \mathrm{H}, 3.94 ; \mathrm{N}, 33.07$. Found: $\mathrm{C}, 56.46 ; \mathrm{H}, 3.78 ; \mathrm{N}$, $33.21 \%$.

2,4-Diamino-6-(2-phenyl-2 H-1,2,3-triazol-4-yl)-6H-1,3-thiazine-5-carbonitrile (5) (0.3 g; 72\%); m.p. $193^{\circ} \mathrm{C}-194^{\circ} \mathrm{C}$; IR: $v_{\max } / \mathrm{cm}^{-1} 3362(\mathrm{NH}), 2236(\mathrm{C} \equiv \mathrm{N})$, and $1638(\mathrm{C}=\mathrm{N}) ; \mathrm{NMR}: \delta_{\mathrm{H}}\left(\mathrm{DMSO}-\mathrm{d}_{6}\right) 7.47-8.05$ $\left(\mathrm{m}, 9 \mathrm{H}\right.$, aromatic- $\left.\mathrm{H}^{+} 2 \mathrm{NH}_{2}\right), 6.69\left(\mathrm{~s}, 1 \mathrm{H}, \mathrm{C} 5{ }^{\prime}-\mathrm{H}\right), 8.48(\mathrm{~s}, 1 \mathrm{H}, \mathrm{C} 5-\mathrm{H}) ; \mathrm{Ms}: \mathrm{m} / \mathrm{z} 297$ (4.3), 296 (10.1), 295 (46.2), 237 (32.5), 171 (12.8), 119 (10.4), 92 (24.5), 91 (92), 90 (14.8), 77 (100), 66 (19.6), 65 (37.9), 64 (94.5), 63 (29.3), 52 (21.4), 51 (58.9). Anal. Calc. for $\mathrm{C}_{13} \mathrm{H}_{11} \mathrm{SN}_{7}: \mathrm{C}, 52.52 ; \mathrm{H}, 3.70 ; \mathrm{N}, 32.29$. Found: C, $52.36 ; \mathrm{H}, 3.82 ; \mathrm{N}, 33.06 \%$.

2-Amino-4-(2-phenyl-2 H-1.2.3-triazol-4-yl)-nicotinonitrile (6): $(0.22 \mathrm{~g}, 63 \%) ; \mathrm{m} . \mathrm{p} .190^{\circ} \mathrm{C}-191^{\circ} \mathrm{C}$; IR: $v_{\max } / \mathrm{cm}^{-1} 3383(\mathrm{NH}), 2219(\mathrm{C} \equiv \mathrm{N})$ and $1626(\mathrm{C}=\mathrm{N})$; NMR: $\delta_{\mathrm{H}}\left(\mathrm{DMSO}-\mathrm{d}_{6}\right) 6.87\left(\mathrm{~s}, 2 \mathrm{H}, \mathrm{NH}_{2}\right), 7.25(\mathrm{~d}$, $\left.1 \mathrm{H}, \mathrm{J}_{5.6}=8.2 \mathrm{~Hz}, \mathrm{C}^{\prime}-\mathrm{H}\right), 7.45-8.06(\mathrm{~m}, 5 \mathrm{H}$, aromatic $-\mathrm{H}), 7.89\left(\mathrm{~d}, 1 \mathrm{H}, \mathrm{J}_{6,5}=9.2 \mathrm{~Hz}, \mathrm{C6}^{\prime}-\mathrm{H}\right), 8.65(\mathrm{~s}, 1 \mathrm{H}$, C5-H). Anal. Calc. for $\mathrm{C}_{14} \mathrm{H}_{10} \mathrm{~N}_{6}$ : C, 64.12; H, 3.82; N, 32.06. Found: C, 64.36; H, 3.58; N, 31.96\%.

4-Amino-2-hydrazinyl-6-(2-phenyl-2 H-1,2,3-triazol-4-yl)-6H-1,3-thiazine-5-carbonitrile (7): (0.3 g; $64 \%) ;$ m.p. $179^{\circ} \mathrm{C}-181^{\circ} \mathrm{C}$; IR: $v_{\max } / \mathrm{cm}^{-1} 3202(\mathrm{NH}), 2241(\mathrm{C} \equiv \mathrm{N})$ and $1642(\mathrm{C}=\mathrm{N})$; NMR: $\delta_{\mathrm{H}}\left(\mathrm{DMSO}-\mathrm{d}_{6}\right)$ $7.41-8.01(\mathrm{~m}, 5 \mathrm{H}$, aromatic $-\mathrm{H}), 8.13(\mathrm{~s}, 2 \mathrm{H}, \mathrm{NH}), 8.20(\mathrm{~s}, 1 \mathrm{H}, \mathrm{C} 6 \mathrm{\prime}-\mathrm{H}), 8.45\left(\mathrm{~s}, 2 \mathrm{H}, \mathrm{NH}_{2}\right), 8.60(\mathrm{~s}, 1 \mathrm{H}$, C5-H), 11.69 (s, 1H, NH). MS: m/z (\%) 313 (86), 265 (16), 235 (66), 206 (36), 169 (31), 143 (18), 119 (17), 92 (21), 77 (100). Anal. Calc. for $\mathrm{C}_{13} \mathrm{H}_{12} \mathrm{SN}_{8}$ : C, 49.99; H, 3.87; N, 35.87. Found: C, 50.01; H, 3.58; N, $35.96 \%$.

2-Amino-4-(2-phenyl-2H-1,2,3-triazol-4-yI)-4,5,6,7-tetrahydrocyclopenta[b] pyran-3-carbonitrile (8): $\left(0.3\right.$ g; 63\%) m.p. $>270^{\circ} \mathrm{C}$; IR: $v_{\max } / \mathrm{cm}^{-1} 3365(\mathrm{NH}), 2236(\mathrm{C} \equiv \mathrm{N})$ and $1625(\mathrm{C}=\mathrm{N})$; NMR: $\delta_{\mathrm{H}}\left(\mathrm{DMSO}-\mathrm{d}_{6}\right)$ $3.13\left(\mathrm{~m}, 6 \mathrm{H}, 3 \mathrm{CH}_{2}\right), 6.69\left(\mathrm{~s}, 2 \mathrm{H}\right.$, exchangeable $\left.\mathrm{NH}_{2}\right), 7.45-8.01(\mathrm{~m}, 5 \mathrm{H}$, aromatic- $\mathrm{H}), 8.42(\mathrm{~s}, 1 \mathrm{H}, \mathrm{C} 4-\mathrm{H})$, 8.57 (s, $1 \mathrm{H}, \mathrm{C} 5-\mathrm{H})$. Anal. Calc. for $\mathrm{C}_{17} \mathrm{H}_{15} \mathrm{~N}_{5} \mathrm{O}: \mathrm{C}, 66.87 ; \mathrm{H}, 4.95 ; \mathrm{N}, 22.94$. Found: $\mathrm{C}, 66.70 ; \mathrm{H}, 4.80 ; \mathrm{N}$, $22.80 \%$.

4-Carboxaldehyde-2-(phenyl-2H-1,2,3-triazole hydrazone (9): A solution of (1 g, $5.78 \mathrm{mmole})$ in ethanol $(20 \mathrm{ml})$ was treated with hydrazine hydrate $(2 \mathrm{ml})$ and acetic acid $(1 \mathrm{ml})$ was heated under reflux for $2 \mathrm{~h}$, concentrated and left to cool. The solid was filtered off, washed with ethanol and dried $(0.65 \mathrm{~g}$, $65 \%)$. It was recrystallized from ethanol as colorless needles, m.p. $115^{\circ} \mathrm{C}-116^{\circ} \mathrm{C}$; IR: $v_{\max } / \mathrm{cm}^{-1} 3218(\mathrm{NH})$ and $1600(\mathrm{C}=\mathrm{N})$. Anal. Calc. for $\mathrm{C}_{9} \mathrm{H}_{9} \mathrm{~N}_{5}: \mathrm{C}, 57.74 ; \mathrm{H}, 4.85 ; \mathrm{N}, 37.41$. Found: $\mathrm{C}, 57.60 ; \mathrm{H}, 4.70 ; \mathrm{N}, 37.80 \%$.

1,2-Bis[(2-phenyl-2 H-1,2,3-triazol-4-yl)] methylene hydrazine (10): A solution of 9 (1 g, $5.35 \mathrm{mmol})$ was treated with 4-carboxaldehyde-2-phenyl-2H-1,2,3-triazole $(1 \mathrm{~g} ; 5.78 \mathrm{mmol})$, boiled under reflux for 3 $\mathrm{h}$, and left to cool. The solid was filtered off and washed with ethanol (yield $0.8 \mathrm{~g}, 60 \%$ ). It was reerystallized from ethanol colorless needles, m.p. $218^{\circ} \mathrm{C}-220^{\circ} \mathrm{C}$; IR: $v_{\max } / \mathrm{cm}^{-1} 1600(\mathrm{C}=\mathrm{N})$ Anal. Calc. for $\mathrm{C}_{18} \mathrm{H}_{14} \mathrm{~N}_{8}$ : C, 63.15; $\mathrm{H}, 4.12$; Found: $\mathrm{C}, 62.89 ; \mathrm{H}, 4.53 \%$.

1-phenyl-3-[(2-phenyl-2 H-1,2,3-triazol-4-yl) methylene hydrazononomethyl-4-(2-phenyl-hydrazono)1 H-pyrazol-5(4H)-one (11). A solution of 9 (1 g; $5.78 \mathrm{mmol}$ ) in ethanol was treated with 3-carboxaldehyde1-phenyl-4,5-pyrazolinedione-4-(phenylhydrazine) (2 g; $6.53 \mathrm{mmol}$ ) was heated under reflux for $3 \mathrm{~h}$, and left to cool. The solid filtered off, washed with ethanol and dried $(1.1 \mathrm{~g}$; $55 \%)$. It was recrystallized from ethanol in orange needles, m.p. $176^{\circ} \mathrm{C}-177^{\circ} \mathrm{C}$; IR: $v_{\max } / \mathrm{cm}^{-1} 3200(\mathrm{NH}), 1659(\mathrm{OCN})$ and $1595(\mathrm{C}=\mathrm{N})$. Anal. Calc. for $\mathrm{C}_{25} \mathrm{H}_{19} \mathrm{~N}_{9} \mathrm{O}: \mathrm{C}, 65.07 ; \mathrm{H}, 4.15$. Found: $\mathrm{C}, 65.53 ; \mathrm{H}, 4.31 \%$.

\section{REFERENCES}

1. El Sekily, M.A., Elba, M.E. and Foad, F.S. (1999) Studies on Dehydro-L-Ascorbic Acid and Dehydro-D-Isoascorbic Acid Hydrazones. Journal of Chemical Research, 296-297.

2. El Sekily, M.A., Elba, M.E. and Foad, F.S. (2000) Some Heterocycles from Dehydro-L-Ascorbic Acid and Dehydro-D-Isoascorbic Acid. Journal of the Indian Chemical Society, 77, 168-171. 
3. El Sekily, M.A. (2006) Studies on Dehydro-D-Erythro-Ascorbic Acid Hydrazone-3-Oximes Conversion into Substituted Triazoles and Isoxazolines. Journal of Chemical Research, 12, 771-774.

4. El Sekily, M.A. (2008) Hydrogenation Products from Dehydro-D-Erythro and Dehydro-L-Theoiso-Ascorbic Acids Mono and Bishydrazones. Arabian Journal for Science and Engineering, 33, 7-14.

5. El Sekily, M.A. and Mancy, S.H. (2011) Reaction of Arylhydrazones of Dehydro-L-Ascorbic Acid and DArabino-2,3-Diulosono-1,4-Lactone. Journal of the Indian Chemical Society, 88, 1-6.

6. Wellinga, K., Grossurt, A.C. and Van Hes, R. (1977) Phenylcarbamoyl-2-Pyrazolines: A New Class of Insecticidal. Synthesis and Insecticital Properties of 3-Phenyl-1-Phenidesylcarbamoyl-2-Pyrazolines. Journal of Agricultural and Food Chemistry, 25, 987-992.

7. Grossurt, A.C., Van Hes, R. and Wellinga, K. (1979) 1-Phenylcarbamoyl-2-Pyrazoline, a New Class of Insecticides. Synthesis and Insecticidal Properties of 3,4-Diphenyl-1-Phenylcarbamoyl-2-Pyrazolines. Journal of Agricultural and Food Chemistry, 27, 406-409.

8. Hasan, R., Nishimura, K. and Okada, M. (1996) Stereochemical Basis for the Insecticidal Activity of Carbamoylated and Acylated Pyrazolines. Pesticide Science, 46, 105-112. https://doi.org/10.1002/(SICI)1096-9063(199602)46:2<105::AID-PS320>3.0.CO;2-Y

9. Biere, H., Böttcher, I. and Kapp, J.F. (1983) Nonsteroidal Anti Inflammatory Agents. Antiphlogistic Pyrazole Derivatives. Archiv der Pharmazie, 316, 588-593.

10. Mizoule, J., Le Far, G. and Uzan, A. (1979) Study of Two New Non-Steroid Anti Inflammatory Drugs Having a Pyrazole Structure. Archives Internationales De Pharmacodynamie Et De Therapie, 238, 305. 